\title{
Renewable Portfolio Standards in the States: Balancing Goals and Implementation Strategies
}

Technical Report NREL/TP-670-41409

December 2007
K.S. Cory

National Renewable Energy Laboratory

B.G. Swezey

Applied Materials 
Renewable Portfolio Standards in the States: Balancing Goals and Implementation Strategies

\author{
K.S. Cory
}

National Renewable Energy Laboratory

B.G. Swezey

Applied Materials

Prepared under Task No. WF6N.1015

National Renewable Energy Laboratory

1617 Cole Boulevard, Golden, Colorado 80401-3393

303-275-3000 • www.nrel.gov

Operated for the U.S. Department of Energy

Office of Energy Efficiency and Renewable Energy

by Midwest Research Institute • Battelle

Contract No. DE-AC36-99-G010337
Technical Report NREL/TP-670-41409

December 2007

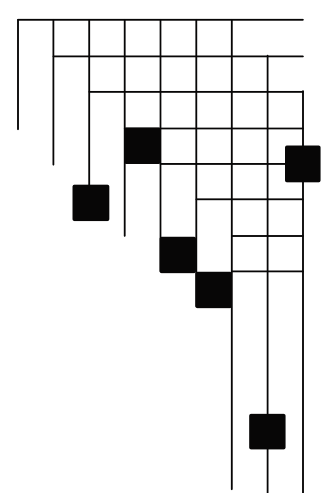




\section{NOTICE}

This report was prepared as an account of work sponsored by an agency of the United States government. Neither the United States government nor any agency thereof, nor any of their employees, makes any warranty, express or implied, or assumes any legal liability or responsibility for the accuracy, completeness, or usefulness of any information, apparatus, product, or process disclosed, or represents that its use would not infringe privately owned rights. Reference herein to any specific commercial product, process, or service by trade name, trademark, manufacturer, or otherwise does not necessarily constitute or imply its endorsement, recommendation, or favoring by the United States government or any agency thereof. The views and opinions of authors expressed herein do not necessarily state or reflect those of the United States government or any agency thereof.

Available electronically at http://www.osti.gov/bridge

Available for a processing fee to U.S. Department of Energy and its contractors, in paper, from:

U.S. Department of Energy

Office of Scientific and Technical Information

P.O. Box 62

Oak Ridge, TN 37831-0062

phone: 865.576 .8401

fax: 865.576 .5728

email: mailto:reports@adonis.osti.gov

Available for sale to the public, in paper, from:

U.S. Department of Commerce

National Technical Information Service

5285 Port Royal Road

Springfield, VA 22161

phone: 800.553.6847

fax: 703.605.6900

email: orders@ntis.fedworld.gov

online ordering: http://www.ntis.gov/ordering.htm 


\section{Preface}

Renewable portfolio standards (RPS) establish a minimum percentage of electricity that retailers must provide from renewable energy sources. However, RPS rules vary from state to state, which presents important challenges to successful implementation. Key issues are discussed in terms of resource availability, solar-specific provisions, and political and regulatory consistency, and their impacts on the ability to finance new renewable energy projects. A successful RPS policy must balance a state's goals for fuel diversity, economic development, price effects, and environmental benefits. 


\section{Acknowledgments}

This work was funded by the U.S. Environmental Protection Agency's (EPA) Climate Protection Partnership Division. The authors wish to thank Joseph Bryson, Niko Dietsch, and the rest of the EPA staff in the Climate Division for their support of this work. The authors also wish to thank Douglas J. Arent, Lori Bird, David Hurlbut, Margaret Mann, David Peterson, and Laura Vimmerstedt of the National Renewable Energy Laboratory (NREL), Ryan Wiser of the Lawrence Berkeley National Laboratory, and Jennifer DeCesaro from the Clean Energy States Alliance for their thoughtful review of the document. Finally, the authors thank Michelle Kubik and Jennifer Josey of NREL for their editorial support. 


\section{Table of Contents}

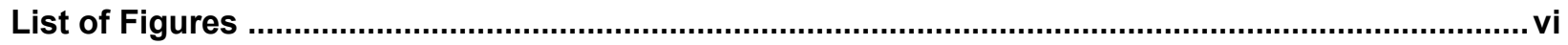

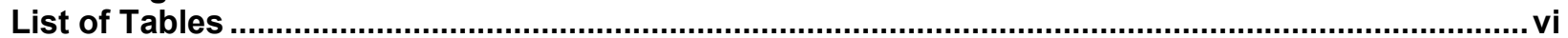

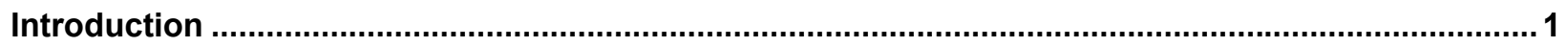

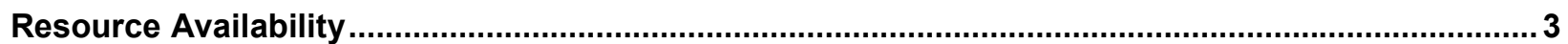

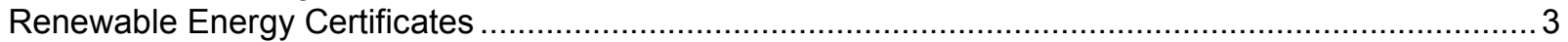

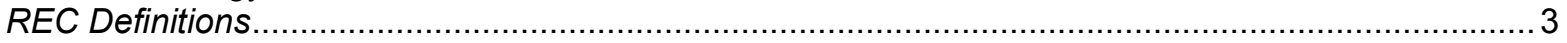

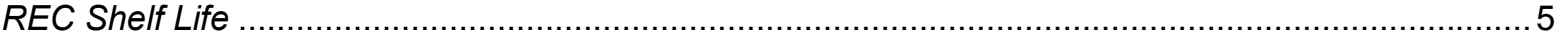

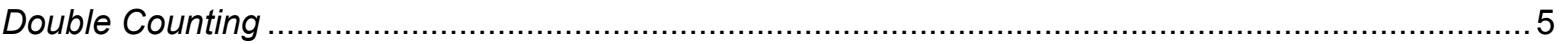

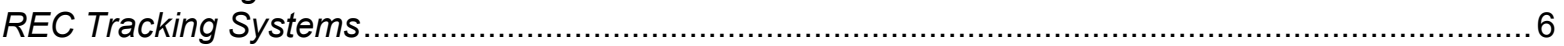

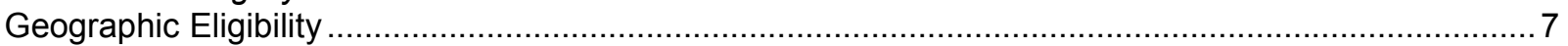

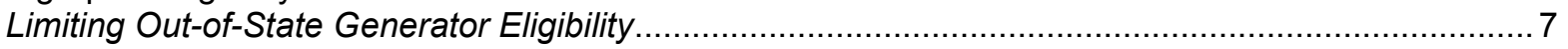

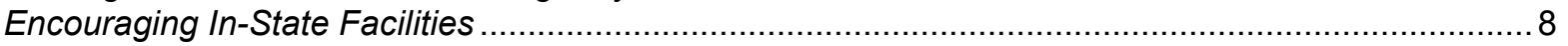

Limiting State Favoritism? The Dormant Commerce Clause .................................................... 9

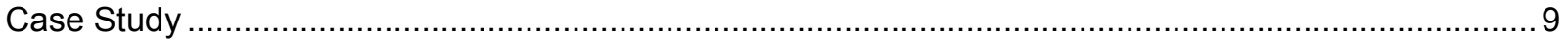

New England Generation Information System: Comprehensive Generation Tracking ....................... 9

Solar-Specific Provisions ...................................................................................................................11

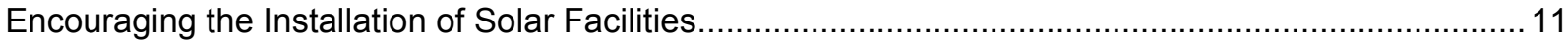

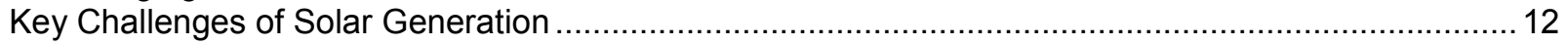

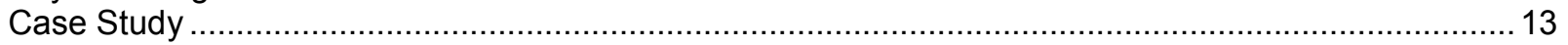

New Jersey Solar Renewable Energy Certificate Tracking ........................................................ 13

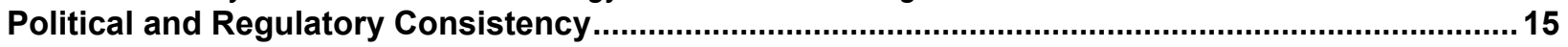

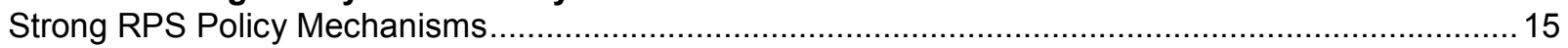

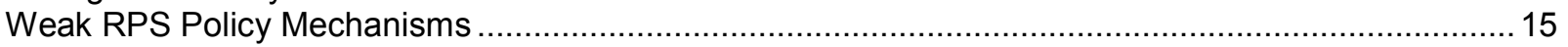

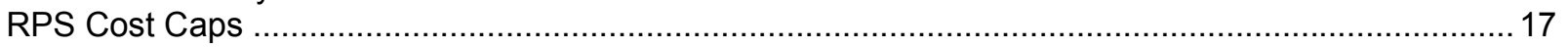

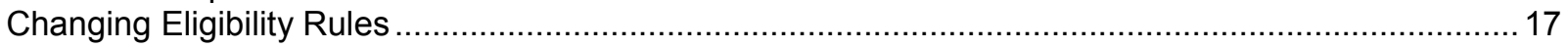

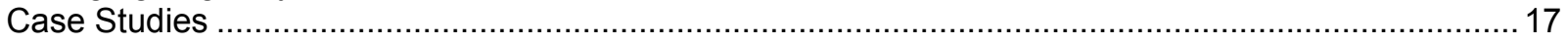

Montana: Compliance Waiver Conditions ............................................................................ 17

Connecticut: Market Impact of Resource Eligibility Changes .................................................... 18

Massachusetts: Market Impact of Resource Eligibility Deliberations ............................................. 18

Texas: Price Impacts on RECs of Ad Hoc Adjustments to RPS Calculation ................................... 19

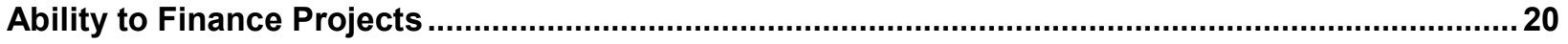

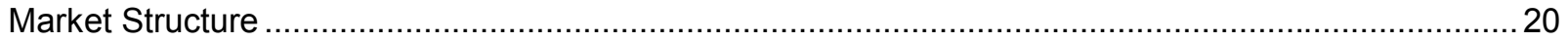

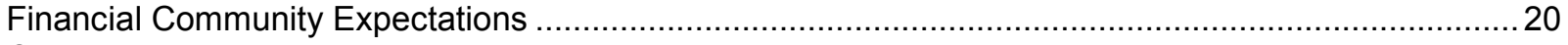

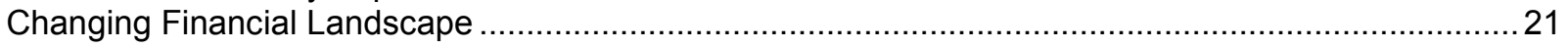

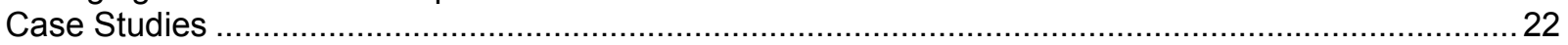

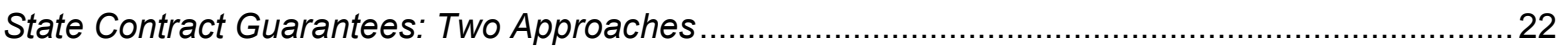

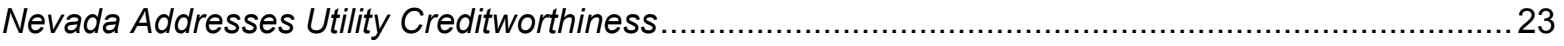

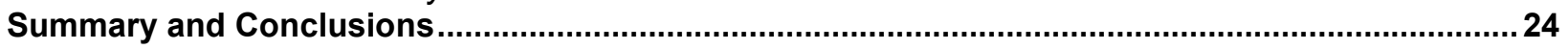

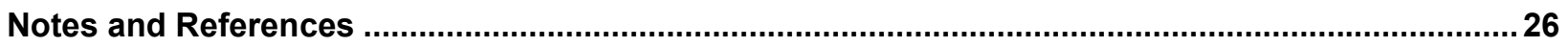




\section{List of Figures}

Figure 1. States with renewable portfolio standards

Figure 2. Renewable energy certificates and attributes creation

Figure 3. Renewable energy certificate tracking systems

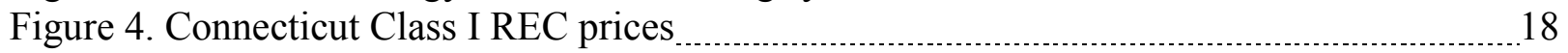

\section{List of Tables}

Table 1. RPS Rules on Resource Eligibility $\ldots \ldots \ldots$

Table 2. RPS Rules on Geographic Eligibility

Table 3. Financial Incentives Offered in States with RPS Solar Set-Asides

Table 4. Current SREC Trading Statistics, Through August 2007

Table 5. State RPS Policies and Noncompliance Penalties 16 


\section{Introduction}

A renewable portfolio standard (RPS) is a policy that requires electricity retailers to provide a minimum percentage or quantity of their electricity supplies from renewable energy sources. An RPS establishes a base level of demand but allows the market to determine which renewable energy resources will meet that demand. Historically, state legislatures and regulatory agencies have been the driving force behind RPS policy formulation, although some RPS polices have been adopted through citizen ballot initiatives. Initially proposed as a mechanism to support renewable energy development in competitively restructured electricity markets, the RPS model today serves additional policy aims such as fuel diversity and in-state economic development.

By the end of 2007, 25 states and the District of Columbia had enacted RPS policies, ranging from $2 \%$ of the electricity supply in Iowa to $40 \%$ in Maine (Figure 1). Three other states, Illinois, Virginia and Vermont, have established nonbinding renewable energy goals. The time horizon for achieving the RPS varies among states. And there are significant differences in state RPS design - such as technology and geographic eligibility, methods that can be used to achieve compliance, and implementation specifics - that make it difficult to generalize about RPS policies nationally.

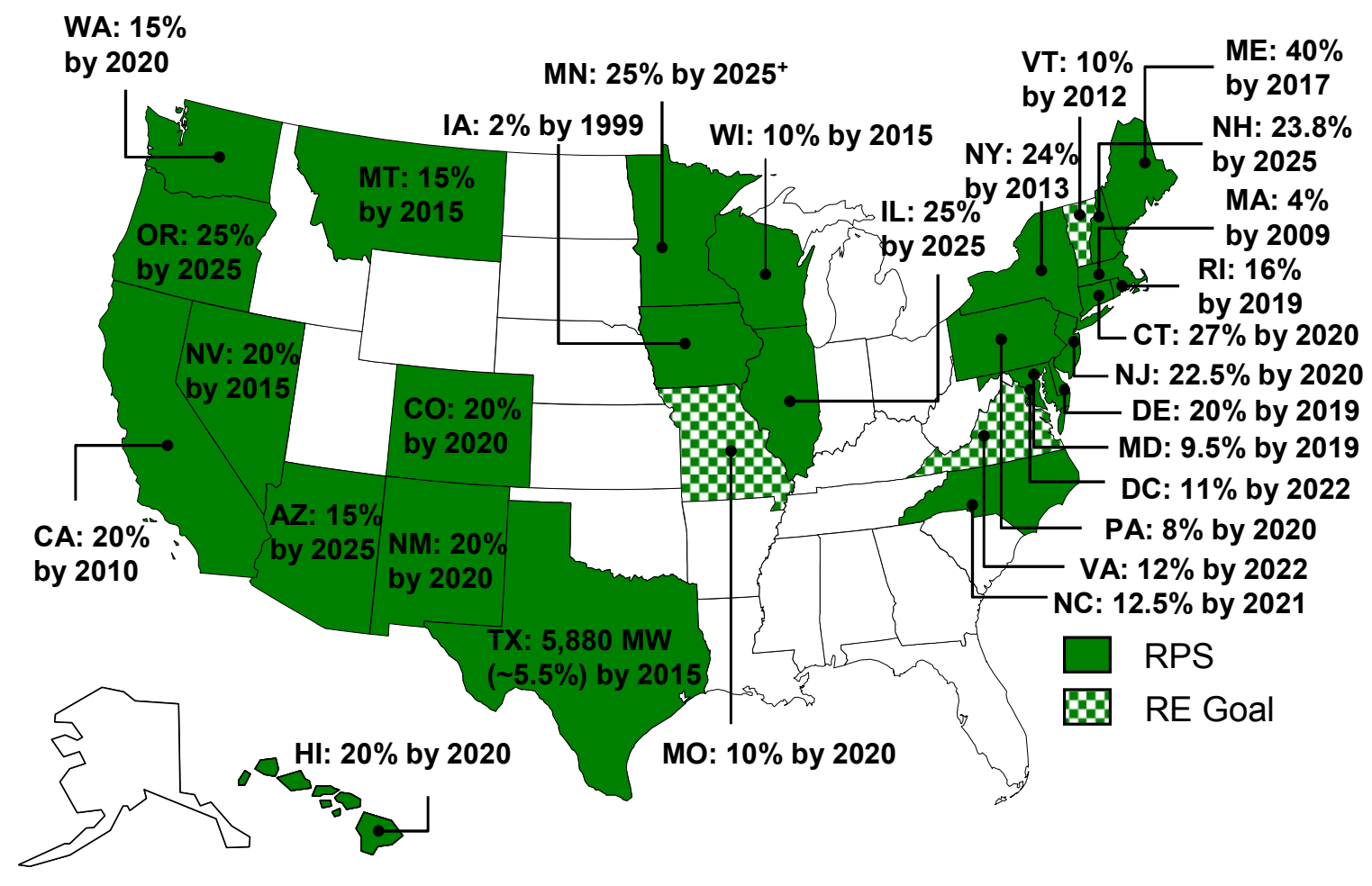

Figure 1. States with renewable portfolio standards 
The U.S. Environmental Protection Agency's (EPA's) Clean Energy-Environment Guide to Action ${ }^{1}$ describes the salient design features of an RPS, such as applicability to market participants, resource eligibility, policy administration, cost caps, and cost recovery. This report goes a step further by examining some specific implementation details and identifying examples of "best practices" used by states.

The RPS implementation issues covered here can be divided into the following categories: resource availability, resource-specific provisions, political and regulatory consistency, and ability to finance new renewable projects.

Renewable resource availability varies widely across the regional climates and geographies of the United States; some states are better endowed with certain renewable resources than others. Geographic limitations contained in state RPS policies can have an important impact on both compliance feasibility and costs. Renewable energy certificates (RECs) have become the prominent mechanism for addressing geographic limitations as well as cost issues, but the use of RECs introduces a number of challenges.

Regarding resource-specific provisions, one important principle of an RPS is to introduce competition into the renewable electricity supply. Some states, however, have established setasides for certain renewable energy resources, particularly for solar energy. Because of their smaller scale and more distributed applications, solar technologies present some unique challenges for RPS compliance, particularly for output measurement and verification.

Both political and regulatory consistency are important. Market confidence can be negatively affected if RPS compliance rules change over time or enforcement is lax. Such factors can include compliance waivers, vague eligibility definitions, low cost impact thresholds, and weak enforcement penalties. Any of these factors can create uncertainty about the stability and longevity of a given RPS policy and undermine investor confidence.

In the end, RPS rules and conditions must allow new projects to be financed and built. Market structure can be important in this regard, particularly whether the market is regulated with a single electricity provider, or restructured for market competition. In either case, the existence of a creditworthy purchasing entity is key.

In this report, we examine all four of these issues in more detail. 


\section{Resource Availability}

To successfully implement an RPS policy, sufficient renewable energy resources must be available. However, renewable resource availability varies widely across the regional climates and geographies of the United States, and the lowest-cost resources may not be accessible within any particular RPS state. Using renewable energy certificates or credits is one mechanism for tapping into the best resources. At the same time, officials must have confidence in both the quality and the legitimacy of RECs.

\section{Renewable Energy Certificates}

RECs are a relatively new market instrument created by separating the "attributes" of renewable electricity generation from the physical electricity produced, thus making RECs a tradable commodity separate from the actual electrons (Figure 2). One REC typically represents the attributes of 1 megawatt-hour (MWh) of renewable electricity generation.

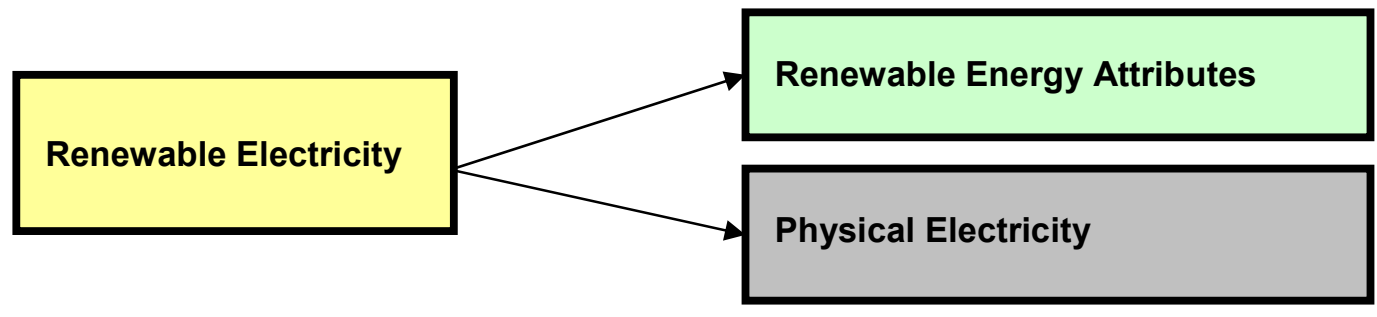

Figure 2. Renewable energy certificates and attributes creation

RECs have many advantages. The use of RECs frees renewable energy sellers from the need to deliver the renewable electricity in real time to the ultimate users. Rather, the electricity, devoid of any attributes, is injected into the grid while the RECs are retained for other uses. The RECs provide an accurate, durable record of what was produced and a fungible commodity that can be traded among suppliers. A REC is spent or "retired" from circulation once it is matched uniquely with an identical quantity of electricity consumed by an end-user.

The use of RECs can reduce the cost of RPS compliance by lowering transmission and distribution costs, while also providing access to a larger quantity of resource options. Finally, RECs provide compliance flexibility by facilitating market trading and increasing market liquidity. As a result, RECs have become the dominant mechanism of RPS compliance. However, the manner in which RECs are defined and treated in RPS policies varies by state and region.

\section{REC Definitions}

State-specific definitions of renewable energy or RECs eligibility tend to segment renewable energy markets across the United States, which results in markets that are smaller and less liquid than they would be if common eligibility definitions were used. This can increase the cost of RPS compliance by limiting the types and sources of renewable energy that can be used for compliance (see Table 1). 
Table 1. RPS Rules on Resource Eligibility

\begin{tabular}{|c|c|c|c|c|c|c|c|c|c|c|c|c|c|}
\hline States & Solar $^{a}$ & Wind & Biomass $^{\mathrm{b}}$ & $\underline{\underline{L F G}}^{\mathrm{c}}$ & Biogas $^{c}$ & MSW & Geoth. & $\underline{\text { All }}$ & $\begin{array}{l}\text { Increm. } \\
\text { Hydro }\end{array}$ & $\underline{\text { Small }}^{\text {Sydro }}{ }^{d}$ & $\begin{array}{l}\text { Fuel } \\
\text { Cells } \\
\end{array}$ & \begin{tabular}{|l|}
$\begin{array}{l}\text { RE-only } \\
\text { Fuel } \\
\text { Cells }\end{array}$ \\
\end{tabular} & $\begin{array}{l}\frac{\text { Ocean } /}{\text { Wavel }} \\
\underline{\text { Tidal }} \\
\end{array}$ \\
\hline Ariz. & $x$ & $x$ & $x$ & $x$ & $x$ & & $x$ & & $x$ & $x$ & & $x$ & \\
\hline Calif. & $x$ & $x$ & $x$ & $x$ & $x$ & $x^{e}$ & $x$ & & & $x$ & & & $x$ \\
\hline Colo. & $x$ & $x$ & $x$ & $x$ & $x$ & & $x$ & & & $x$ & & $x$ & \\
\hline Conn. & $x$ & $x$ & $x$ & $x$ & & $x$ & & & & $x$ & $x$ & & $x$ \\
\hline Del. & $x$ & $x$ & $x$ & $x$ & $x$ & $\mathrm{x}$ & $x$ & & & $x$ & & $x$ & $x$ \\
\hline D.C. & $x$ & $x$ & $x$ & $x$ & $x$ & $\mathrm{x}$ & $x$ & $x$ & & & & $x$ & $x$ \\
\hline Hawaii & $x$ & $x$ & $x$ & $x$ & $x$ & $x$ & $x$ & $x$ & & & & $X$ & $x$ \\
\hline Illinois & $x$ & $x$ & $x$ & $x$ & & & & & $x$ & & & & \\
\hline lowa & $x$ & $x$ & $x$ & $x$ & $x$ & $x$ & & & & $x$ & & & \\
\hline Maine & $x$ & $x$ & $x$ & $x$ & & $x$ & $x$ & $x$ & & & $x$ & & $x$ \\
\hline Md. & $x$ & $x$ & $x$ & $x$ & $x$ & $x$ & $x$ & $x$ & & & & $X$ & $x$ \\
\hline Mass. & $x$ & $x$ & $x$ & $x$ & $x$ & $\mathrm{x}$ & & $x$ & & & & $x$ & $x$ \\
\hline Minn. & $x$ & $x$ & $x$ & $x$ & $x$ & $x$ & & & & $x$ & & $x$ & \\
\hline Mont. & $x$ & $x$ & $x$ & $x$ & $x$ & & $x$ & & & $x$ & & $x$ & \\
\hline Nev. & $x$ & $x$ & $x$ & $x$ & $x$ & $x$ & $x$ & & & $x$ & & & \\
\hline N.H. & $x$ & $x$ & $x$ & $x$ & $x$ & & $x$ & & & $x$ & & & $x$ \\
\hline N.J. & $x$ & $x$ & $x$ & $x$ & & $x$ & $x$ & & & $x$ & $x$ & & $x$ \\
\hline N.M. & $x$ & $x$ & $x$ & $x$ & $x$ & & $x$ & & $x$ & & & $x$ & \\
\hline N.Y. & $x$ & $x$ & $x$ & $x$ & $x$ & & & $x$ & $x$ & $x$ & $x$ & & $x$ \\
\hline N.C. & $x$ & $x$ & $x$ & $x$ & $x$ & & $x$ & & & $x$ & & & $x$ \\
\hline Ore. & $x$ & $x$ & $x$ & $x$ & $x$ & & $x$ & $x$ & & & & $x$ & $x$ \\
\hline Pa. & $x$ & $x$ & $x$ & $x$ & $x$ & $x$ & $x$ & $x$ & & $x$ & $x$ & & \\
\hline R.I. & $x$ & $x$ & $x$ & $x$ & $x$ & & $x$ & & & $x$ & & $x$ & $x$ \\
\hline Tex. & $x$ & $x$ & $x$ & $x$ & & & $x$ & $x$ & & & & & $x$ \\
\hline Wash. & $x$ & $x$ & $x$ & $x$ & $x$ & & $x$ & & $x$ & & & & $x$ \\
\hline Wis. & $x$ & $x$ & $x$ & $x$ & & & $x$ & & & $x$ & & $x$ & $x$ \\
\hline
\end{tabular}

${ }^{a}$ Can include thermal energy.

${ }^{\mathrm{b}}$ Can also be included in biomass definition.

${ }^{\mathrm{c}}$ Can include co-firing and come with emission limits or sustainable growth conditions.

${ }^{\mathrm{d}}$ Various size, technology, and vintage definitions.

${ }^{e}$ MSW combustion is eligible if in Stanislaus County and operational before September 26, 1996. MSW conversion is eligible if it gasifies the MSW into a clean burning fuel, which is then used to generate electricity.

Sources: Union of Concerned Scientists 2007; Database of State Incentives for Renewables \& Efficiency (www.dsireusa.org); and individual state RPS legislation.

State-specific definitions also work against the development of a larger spot market for renewable energy attributes. Spot markets provide for more efficient market operation by providing publicly available pricing information that helps to inform market participants. However, without adequate market volume, a spot market is unlikely to develop. The result is that today, with few exceptions, the majority of REC sales are bilateral (i.e., conducted between one buyer and one seller in a private transaction in which pricing information remains confidential).

Varying REC definitions can be the source of an additional burden on project developers, especially when it comes to state-specific eligibility certification. Developers and investors are more likely to pursue a new renewable energy project if there are multiple market outlets for the 
project output. Reliance on a single state RPS market also exposes the project to the risk of future RPS rule changes. And differences in REC shelf lives between markets can create an additional challenge.

\section{REC Shelf Life}

The shelf life of a REC (i.e., the length of time during which a REC can be used for compliance) can be as short as three months (in New England) to as long as four years (in Nevada and Wisconsin). ${ }^{2}$ Because renewable energy generation can vary on both a seasonal and an annual basis due to changing weather patterns, longer REC lives increase the ability of the market to smooth out these variations. In addition, the ability to "bank" RECs helps address supply and demand imbalances that result from project construction intervals as well as the "lumpiness" of new supply additions.

Even some states that have adopted shorter REC lives allow generation to be banked, so that any oversupply in one year can be used for compliance in subsequent years. For example, Massachusetts allows banking for two years to meet up to $30 \%$ of the annual requirement; Delaware, Maryland, and Washington, D.C. allow a three-year banking period, and California allows indefinite banking. ${ }^{3}$ Whether states adopt longer REC lives or banking, it is important to place some finite limit on REC life, otherwise an oversupply of vintage RECs could reduce demand for new production.

\section{Double Counting}

Double counting occurs when more than one entity claims ownership of a REC or of the REC and its associated power. This can be a serious issue in RPS implementation and for renewable energy markets in general. A vibrant market has developed for renewable energy attributes for use both in policy compliance and in voluntary markets in which purchasers seek to make claims about the environmental benefits (e.g., carbon emissions reductions) of their renewable energy purchases. ${ }^{4}$ Double counting of these attributes has the potential to undermine both markets.

Policy makers may be tempted to count any and all renewable energy generated in a state toward RPS compliance. This is a particularly serious issue where markets exist for voluntary renewable energy (or "green power") purchases. By counting voluntary purchases, suppliers may have an easier time meeting the RPS requirements. On the other hand, counting voluntary market sales toward RPS compliance undermines one of the fundamental tenets of these markets - that an individual consumers' voluntary purchase supports renewable energy development over and above the development that occurs otherwise (e.g. as a result of policy mandates, for which all customers share the cost)..$^{5}$ An RPS is designed to "prime the pump" and enable a wider market for renewable power; it is not designed to limit total demand.

Most states with an RPS policy have determined that voluntary green power purchases should not be counted toward RPS compliance. ${ }^{6}$ For example, Minnesota has both an RPS and a requirement for the state's utilities to offer their customers a voluntary renewable energy purchase ("green pricing") option. In considering how to integrate these two policies, the Minnesota Public Utilities Commission determined that counting green pricing sales toward the renewable energy requirements was not consistent with the public interest or with other state energy policies that seek to encourage renewable energy development. ${ }^{7}$

In Texas, however, a 2005 law that increased the state's RPS also required that all renewable energy generated in the state, including that associated with voluntary purchases, count toward 
RPS compliance. ${ }^{8}$ The Texas legislature reversed this decision in June 2007, by repealing this provision. ${ }^{9}$ If this subsection remained, it could have had a deleterious effect on voluntary market sales from Texas-based renewable energy projects, because most voluntary market customers expect their purchases to be additional to any policy requirements. The additional nature of purchases is a primary requirement of the Green-e certification program, as well as for membership in U.S. Environmental Protection Agency's Green Power Partnership. ${ }^{10}$

In many cases, voluntary green power programs have preceded the establishment of a state RPS mandate. Voluntary green power markets have raised the public's awareness of and support for renewables, provided utilities with experience in the operation and grid integration of renewable energy technologies, and built new constituencies for renewable energy among rural landowners and farmers. In fact, a recent NREL report found that "customer participation rates in utility green power programs were higher on average in states with an RPS than in those without." 11 Many renewable energy project developers support the existence of both markets to provide revenue options and to reduce the risk of holding unutilized renewable energy generation. ${ }^{12}$ All of these outcomes have provided key arguments and support for adopting an RPS policy.

Other double counting issues relate to renewable energy attributes supplied from facilities installed under the Public Utility Regulatory Policies Act (PURPA) of 1978 - projects that receive subsidies or incentive payments from the state or from utilities, and customer-owned systems that are interconnected to the utility grid and benefit from net metering arrangements. There are legitimate questions regarding ownership of the attributes associated with renewable energy generation in the absence of contractual language that clearly addresses this issue. In particular, several thousand megawatts of renewable energy qualifying facility $(\mathrm{QF})$ projects were installed under rules governed by PURPA, long before RPS policies were first established.

A 2006 report issued by Lawrence Berkeley National Laboratory (LBNL) documents how state decision makers have ruled on these issues. ${ }^{13}$ Most states ruling on the issue of pre-existing QF contracts have decided that renewable QF project attributes are conveyed to the power purchaser, thus allowing a utility or other supplier to count this generation toward its RPS compliance. ${ }^{14}$ In general, newer QF contracts will contain language addressing attributes ownership. On the other hand, most states ruling on net-metered projects have decided that the RECs belong to the customer-generator. Fewer states have ruled on projects benefiting from financial incentives, with mixed decisions.

\section{REC Tracking Systems}

REC tracking systems provide a mechanism for regulators to easily verify and trace REC ownership. ${ }^{15}$ REC tracking systems are now operating in Texas/ERCOT, New Jersey (solaronly), New England, the Pennsylvania-New Jersey-Maryland (PJM) interconnect, the Midwest, and Western grid regions. An additional REC trading system is under development in New York. These REC tracking platforms have been designed for the specific state or regional circumstances. As more states employ REC tracking systems to monitor RPS compliance, the trading of RECs between systems with divergent definitions and tracking structures will have to be addressed. 


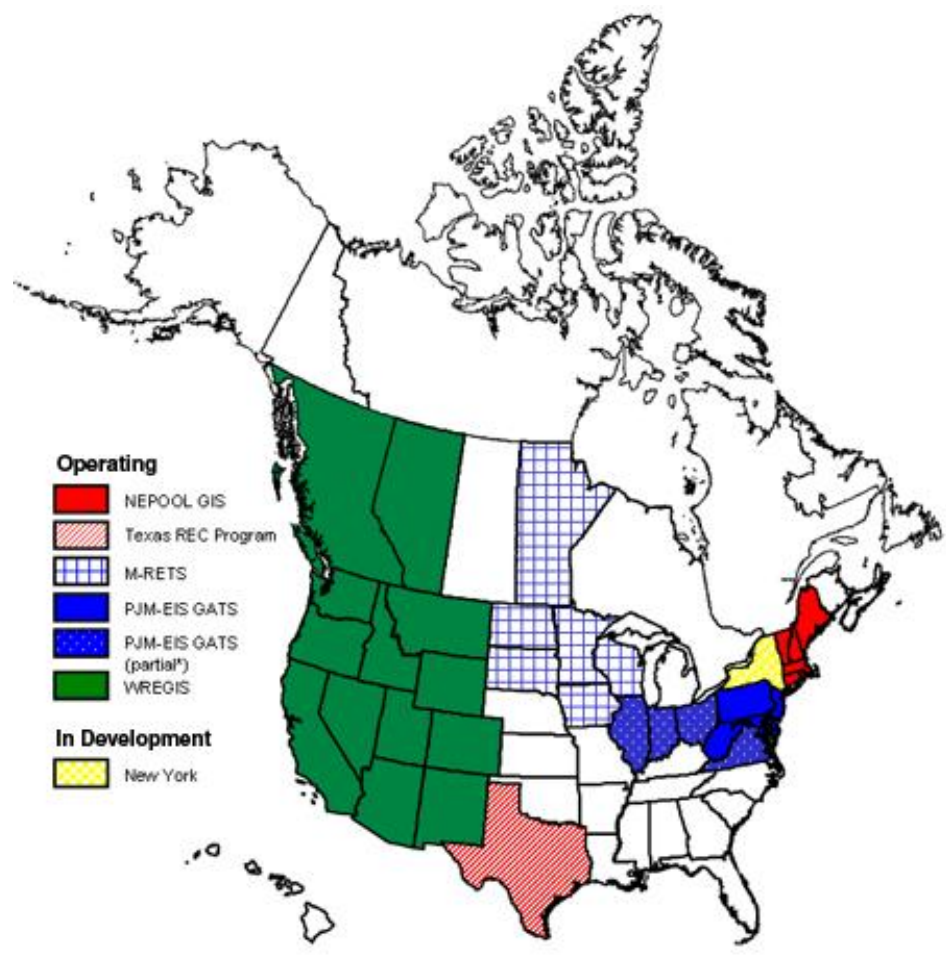

Figure 3. Renewable energy certificate tracking systems Source: U.S. EPA, $2007^{16}$

Key challenges relate to whether and how to allow for interregional trading, and how to protect against double counting between states and regions. The Center for Resource Solutions has been facilitating a discussion of seams issues between REC tracking platforms through the North American Association of Issuing Bodies (NAAIB). NAAIB is a voluntary organization working to promote compatibility among tracking systems to prevent double counting. ${ }^{17}$ Whether REC trading between systems occurs or not, the possibility (or lack thereof) should be clearly defined so that market players can understand the rules under which REC trading and transfer can occur.

\section{Geographic Eligibility}

One key rationale for states to adopt an RPS is the benefit, in terms of more jobs and greater income, of renewable energy resource and project development. Other benefits include fewer harmful air emissions and greater fuel diversification. In this respect, some states have established policies to restrict market access from outside the state or region, or to otherwise favor in-state or in-region development. Their goal in doing so is to capture most of the benefits locally. However, in limiting geographic eligibility, a state may forego cost savings that could be achieved if out-of-state resources could be tapped.

\section{Limiting Out-of-State Generator Eligibility}

Geographic eligibility rules differ widely among states. Some RPS policies require that certain renewable facilities be built within the state or require a facility to be directly interconnected to the state grid. Other states are less restrictive, requiring only that the energy be delivered to the state. Still others allow energy and REC delivery to a regional control area or regional transmission organization (RTO). Finally, a small number of states allow the use of RECs without electricity delivery if certain conditions are met (see Table 2). 
Table 2. RPS Rules on Geographic Eligibility

\begin{tabular}{|c|c|}
\hline State & Geographic Eligibility \\
\hline Arizona & State generation or interconnection \\
\hline California & State generation or delivery (CAISO) ${ }^{\mathrm{a}}$ \\
\hline Colorado & No restrictions \\
\hline Connecticut & Regional generation or delivery (ISO-NE) ${ }^{a}$ \\
\hline Delaware & Regional generation or delivery (PJM) ${ }^{\mathrm{a}}$ \\
\hline $\begin{array}{l}\text { District of } \\
\text { Columbia }\end{array}$ & Regional generation or delivery (PJM) or from states adjacent to PJM \\
\hline Hawaii & In-state projects only \\
\hline Illinois & In-state projects only, unless cost-effective alternative available from adjacent state \\
\hline lowa & In-state projects only \\
\hline Maine & Regional generation or delivery (ISO-NE) \\
\hline Maryland & Regional generation or delivery (PJM) or from states adjacent to PJM \\
\hline Massachusetts & Regional generation or delivery (ISO-NE) \\
\hline Minnesota & State generation or delivery \\
\hline Montana & State generation or delivery \\
\hline Nevada & State generation or delivery \\
\hline New Hampshire & Regional generation or delivery (ISO-NE) \\
\hline New Jersey & Regional generation or delivery (PJM) \\
\hline New Mexico & State generation or delivery \\
\hline New York & State generation or delivery (NYISO) ${ }^{a}$ \\
\hline North Carolina & State generation or delivery \\
\hline Oregon & Regional generation or delivery \\
\hline Pennsylvania & Regional generation or delivery (PJM) \\
\hline Rhode Island & Regional generation or delivery (ISO-NE) \\
\hline Texas & State generation or interconnection \\
\hline Washington & Regional location or state delivery \\
\hline Wisconsin & State generation or delivery \\
\hline
\end{tabular}

Some states and regions are limiting out-of-state renewable energy delivery, not through RPS policies but through the design of their REC tracking systems. For example, the New England Power Pool's Generation Information System (NEPOOL-GIS) restricts the participation of outof-region projects by requiring that firm transmission into the region be purchased to match a renewable facility's generation on an hourly basis. If a facility does not have firm transmission into New England during the exact hour that it generates power, a NEPOOL-GIS REC will not be created. New York followed suit by requiring hourly matching after previously approving a monthly transmission matching system. ${ }^{18}$ Monthly matching (e.g., as adopted by GATS) provides more flexibility by accepting RECs from out-of-state facilities as long as the power wheeled in a month matches the total renewable generation output over that same month.

\section{Encouraging In-State Facilities}

Some states have designed their RPS policy specifically to favor in-state facilities, such as providing extra compliance credit to in-state facilities or by creating set-asides for customer- 
owned systems. And some states employ complementary policies that encourage in-state renewable generation; these include rebates, state tax incentives, public benefit funding, and net metering.

Rebate programs provide a monetary reimbursement for constructing a new renewable facility, usually to a homeowner or business, and these programs may be offered at the state, local, or utility level. State tax incentives may include production tax credits, reduced or exempted property taxes, or exemptions from state sales tax on purchases of renewable energy equipment. Public benefit funds (also known as system benefit charge funds), which are commonly supported through a ratepayer charge on electricity consumption, are often used to help develop new renewable energy systems, increase consumer demand, and support in-state renewable energy industry development. Finally, 40 states have adopted net metering, under which eligible customer-generators are credited for renewable generation in excess of their demand. ${ }^{19}$

\section{Limiting State Favoritism? The Dormant Commerce Clause}

According to the so-called dormant commerce clause of the U.S. Constitution, no state can favor an in-state commodity over an out-of-state equivalent. Specifically, "The U.S. Supreme Court consistently strikes down as unconstitutional [programs] involving interstate goods taxed by states so as to provide local subsidy." 20 The dormant commerce clause thus raises questions as to the legality of RPS rules that limit out-of-state eligibility.

To date, no state RPS policies have been challenged on the basis of the dormant commerce clause. Clearly, however, state rules that require eligible facilities to be physically located instate or directly interconnected into the state are at risk. Less clearly at risk are rules that require power to be delivered to the state or regional control area and rules that favor distributed or onsite generation.

\section{Case Study}

\section{New England Generation Information System: Comprehensive Generation Tracking}

The New England Generation Information System (NE-GIS) was created to efficiently track the environmental attributes of power in the New England power pool (NEPOOL) separate from the energy commodity (http://www.nepoolgis.com). The system began operations in April 2002 and creates one certificate for each MWh of energy generated or imported into New England (both energy and RECs must be imported). The NE-GIS allows retail electric suppliers to easily track and report compliance with RPS requirements, disclose fuel source and other characteristics of power sold, and to report emission levels. It also provides an easy way for regulators to confirm compliance with regulations and provides them with specific reports. It does not provide any price transparency of REC or other certificate transactions.

Initial discussions to build such a tracking system were started by Massachusetts and Connecticut, who were among the first states to enact mandatory RPS requirements. Their regulators recognized the importance of developing a renewable energy certificate (REC) tracking system that would prevent double counting, because of the interconnected nature of the 
New England power pool and the potential for renewable facilities throughout the region to qualify in both states.

Regulators from New England states were brought together to discuss creating a regional tracking system. It soon became clear that RPS mandates were being considered in other New England states and that other requirements might necessitate coordinated tracking, such as emission/generation portfolio standards for criteria pollutants, or potentially carbon. Rather than develop a separate tracking system for each requirement, the region decided to create a single tracking system that tracks all NEPOOL generation, including renewable, fossil-fired, and nuclear. The NE-GIS tracks when, where, and who produced the power; the type of fuel source used; the amount and type of pollutants - including $\mathrm{NO}_{\mathrm{X}}, \mathrm{SO}_{2}, \mathrm{CO}_{2}, \mathrm{CO}$, Mercury, particulates, fine particulates and organic compounds; and also RPS-eligibility by state (since requirements differ). Most other states and regions focused exclusively on REC tracking, without the foresight to allow expansion to track emissions as well. 


\section{Solar-Specific Provisions}

Some states have established RPS carve-outs or set-asides for particular renewable energy technologies. This is usually done to support promising technologies with valuable characteristics that might otherwise be shut out of the market because of their higher costs. Solar energy has been the primary recipient of most RPS set-aside rules. The correlation between solar electricity generation and peak summer loads is very high, and solar generation lends itself well to distributed or on-site applications. Solar can also be valuable in load-congested areas, where siting and emissions considerations can limit power generation options.

\section{Encouraging the Installation of Solar Facilities}

In 13 RPS programs, ${ }^{21}$ solar energy installations are being encouraged in several ways. For example, states can specify a certain quantity or percentage of the RPS that must be met with solar resources so that solar does not have to compete with other renewables. To date, nine states and the District of Columbia have established specific solar set-asides in their RPS policies. Another tactic used in three RPS programs is to have set-asides for customer-sited or distributed systems, which tend to favor solar. Finally, five RPS policies offer extra credit to either solar or distributed generation (DG); for example, DG and/or solar RECs are assigned greater weight toward compliance than other RECs. The intent of this mechanism is to provide a greater incentive to use DG and solar for RPS compliance. In some states, extra credits have also been used to promote other technologies (e.g., wind or fuel cells) or other actions (e.g., early compliance). Collectively, these provisions could result in several thousands of MW of installed solar electric capacity by 2025; for example, Maryland's solar set-aside is expected to result in $1500 \mathrm{MW}$ of new solar capacity. ${ }^{22}$

Because solar energy remains relatively expensive when compared with other renewable energy technologies, states with solar set-asides may also offer financial incentives to assist with solar compliance. For example, New Jersey offered a rebate for customer-owned solar electric systems that ranged from $\$ 3.80 /$ watt $(\mathrm{W}$ ) to $\$ 4.40 / \mathrm{W}$ and resulted in $40.9 \mathrm{MW}$ of new solar PV capacity; ${ }^{23}$ however, they are currently restructuring their rebates. Similarly, Colorado offers a $\$ 2.00 / \mathrm{W}$ system rebate, but also offers another $\$ 2.50 / \mathrm{W}$ to compensate customers for the solar RECs that the utility then applies toward RPS compliance (see Table 3). 
Table 3. Financial Incentives Offered in States with RPS Solar Set-Asides

\begin{tabular}{|c|c|}
\hline State & Incentive \\
\hline Arizona & $\$ 2.00$ to $\$ 3.00 / \mathrm{W}$ system rebate ${ }^{a}$ \\
\hline Colorado & $\$ 2.00 / \mathrm{W}$ system rebate $+\$ 2.50 / \mathrm{W}$ RECs payment ${ }^{b}$ \\
\hline Delaware & $\begin{array}{l}\text { System rebate up to } 50 \% ; \$ 22.5 \mathrm{~K} \text { maximum for residential, } \$ 250 \mathrm{~K} \\
\text { maximum for non-residential }\end{array}$ \\
\hline $\begin{array}{l}\text { District of } \\
\text { Columbia }\end{array}$ & No incentives available \\
\hline Maryland & $\begin{array}{l}\text { System rebate up to } 20 \% ; \$ 3 \mathrm{~K} \text { maximum for residential, } \$ 5 \mathrm{~K} \\
\text { maximum for non-residential }\end{array}$ \\
\hline Nevada & $\begin{array}{l}\$ 3.00 / \mathrm{W} \text { system rebate for residential and small business } \\
\$ 5.00 / \mathrm{W} \text { system rebate for schools and public buildings }\end{array}$ \\
\hline New Hampshire & No incentives available \\
\hline New Jersey* & $\begin{array}{l}\$ 3.50 / \mathrm{W} \text { rebate on private site for } 0-10 \mathrm{~kW}(+\$ 0.6 / \mathrm{W} \text { for schools }) \\
\$ 2.50 / \mathrm{W} \text { rebate on private site for } 10-40 \mathrm{~kW}(+\$ 0.65 / \mathrm{W} \text { for schools }) \\
\$ 2.25 / \mathrm{W} \text { rebate on private site for } 40-100 \mathrm{~kW}(+\$ 0.25 / \mathrm{W} \text { for schools }) \\
\$ 2.0 / \mathrm{W} \text { rebate on private site for } 100-500 \mathrm{~kW}(+\$ .3 / \mathrm{W} \text { for schools }) \\
\$ 1.75 / \mathrm{W} \text { for } 500-700 \mathrm{~kW}^{\mathrm{c}} \\
{ }^{*} \mathrm{New} \text { Jersey Solar Rebates on hold until new funding is available }\end{array}$ \\
\hline New Mexico & $13 \phi / \mathrm{kWh}$ for systems up to $10 \mathrm{~kW}^{\mathrm{d}}$ \\
\hline New York & $\begin{array}{l}\$ 4.00 / \mathrm{W} \text { to } \$ 4.50 / \mathrm{W} \text { system rebate up to } 5 \mathrm{~kW} \text { for residential and } 25 \\
\mathrm{~kW} \text { for non-residential; } \\
\$ 3.00 / \mathrm{W} \text { to } \$ 3.50 / \mathrm{W} \text { system rebate for capacity above } 5 \mathrm{~kW} \text { for } \\
\text { residential and } 25 \mathrm{~kW} \text { for non-residential; } \\
\text { Capped at } 60 \% \text { of installed costs for up to } 10 \mathrm{~kW} \text { for residential and } \\
100 \mathrm{~kW} \text { for non-residential, and }\end{array}$ \\
\hline North Carolina & No incentives available \\
\hline Pennsylvania & No incentives available \\
\hline \multicolumn{2}{|c|}{$\begin{array}{l}\text { Arizona Public Service Solar Partners incentive program. The state also provides a } 10 \% \text { corporate tax credit and a } \\
\text { personal tax credit. } \\
\text { bECs payment amount is for Xcel Energy's Solar* Rewards incentive program for systems } 10 \mathrm{~kW} \text { or less in size; th } \\
\text { RECS payment for larger systems is } 11.5 \phi / k W h \text {. } \\
\text { c NJ BPU Clean Energy Office is currently restructuring the solar energy programs and incentives } \\
\text { d PNM Customer Solar PV program }\end{array}$} \\
\hline
\end{tabular}

\section{Key Challenges of Solar Generation}

Most solar systems are customer-owned and sited, which presents certain challenges for verifying system output. Installing a second meter to separately measure system output is a common verification approach, but this adds to the cost of the system. Engineering estimates of system performance may also be used, but this method cannot account for periods of time when the system is down. And while these estimates can account for seasonal and daily variations, they cannot predict exact output. The engineering estimates approach is often coupled with spot audits to confirm operational characteristics and output.

Apportioning the costs of verifying system output must also be addressed. State approaches are mixed in assigning these costs to either the customer or the utility. In either case, the responsibility for verification costs should be made clear at the outset.

Finally, establishing ownership of solar RECs can be an issue. In Colorado, a portion of the system rebate is meant to compensate the customer-generator for the solar RECs that the utility then applies toward its compliance with the solar set-aside. However, in New Jersey, the 
customer-generator retains ownership of solar RECs, and suppliers must purchase RECs separately to meet the solar requirements. State policy on RECs ownership should also be addressed early in the process.

\section{Case Study}

\section{New Jersey Solar Renewable Energy Certificate Tracking}

New Jersey created a separate solar tier in their RPS to encourage a minimum amount of solar generation that would not have to compete with more cost-effective renewable generation. New Jersey's Board of Public Utilities contracted with Clean Power Markets to administer the state's solar REC tracking system for solar RECs, or SRECs. ${ }^{24}$ SRECs are issued in $1 \mathrm{MWh}$ denominations and are sold or traded separately from the underlying power.

There are a few unique aspects of this tracking system. First, behind-the-meter solar generation is encouraged to sign up for an account, which is not true in all REC tracking systems. The administrator maintains a database of all participating solar systems in New Jersey, no matter their size. Therefore, the SREC trading platform specifically allows behind-the-meter generation to create SRECs and participate in trading. Second, the system provides the market with price transparency. Anyone who transfers an SREC has to report the price of the transaction to the administrator, who publicly posts the average price of all transactions that took place that month (see Table 4). Information on the Web site describes monthly SREC weighted-average prices from August 2004 forward. While the prices of specific transactions are kept confidential, the availability of monthly market SREC prices creates a price history that is publicly accessible and ultimate increases investor confidence in the validity of the SREC as a commodity. This is lacking in most REC markets and has been pointed out as a definite need going forward, particularly by debt and equity investors. Finally, Clean Power Market's maintains an actively used bulletin board where people post RECs to sell, and where others post their desire to purchase RECs, listing their bids/offer prices. This allows buyers and sellers to easily find each other in the market, particularly if they do not know who to approach. These unique characteristics mean that the New Jersey SREC tracking system is providing the market with additional value not found in most other REC tracking systems. 
Table 4. Current SREC Trading Statistics, Through August 2007

\begin{tabular}{|c|c|c|c|c|c|c|c|c|}
\hline Month & Year & $\begin{array}{l}\text { Active kw } \\
\text { DC }\end{array}$ & $\begin{array}{l}\text { \# SRECs } \\
\text { Issued } \\
\text { in Month }\end{array}$ & $\begin{array}{c}\text { \# SRECs } \\
\text { Traded } \\
\text { in Month }\end{array}$ & $\begin{array}{l}\text { Monthly } \\
\text { High } \\
\text { (\$/MWh) }\end{array}$ & $\begin{array}{l}\text { Monthly } \\
\text { Low } \\
\text { (\$/MWh) }\end{array}$ & $\begin{array}{c}\text { Cumulative } \\
\# \\
\text { SRECs } \\
\text { Traded }\end{array}$ & $\begin{array}{l}\text { Cumulative } \\
\text { Weighted } \\
\text { Average } \\
\text { Price } \\
\text { (\$/MWh) }\end{array}$ \\
\hline August & 2007 & $38,861.17$ & 541 & 8913 & $\$ 250$ & $\$ 88$ & 53932 & $\$ 220.28$ \\
\hline July & 2007 & $38,670.88$ & 1066 & 9851 & $\$ 265$ & $\$ 150$ & 45019 & $\$ 221.27$ \\
\hline June & 2007 & $37,934.50$ & 8239 & 17463 & $\$ 297$ & $\$ 110$ & 35168 & $\$ 218.62$ \\
\hline May & 2007 & $35,738.462$ & 5493 & 3375 & $\$ 265$ & $\$ 150$ & 17705 & $\$ 217.96$ \\
\hline April & 2007 & & 2479 & 2527 & $\$ 265$ & $\$ 150$ & 14330 & $\$ 214.75$ \\
\hline Mar & 2007 & & 2127 & 1828 & $\$ 265$ & $\$ 150$ & 11803 & $\$ 208.65$ \\
\hline Feb & 2007 & & 1744 & 3067 & $\$ 265$ & $\$ 110$ & 9975 & $\$ 205.65$ \\
\hline Jan & 2007 & & 1194 & 1557 & $\$ 265$ & $\$ 115$ & 6908 & $\$ 204.03$ \\
\hline Dec & 2006 & & 1681 & 2750 & $\$ 260$ & $\$ 110$ & 5351 & $\$ 195.44$ \\
\hline Nov & 2006 & & 1820 & 1022 & $\$ 260$ & $\$ 110$ & 2601 & $\$ 197.89$ \\
\hline Oct & 2006 & & 2622 & 464 & $\$ 250$ & $\$ 160$ & 1579 & $\$ 205.99$ \\
\hline Sept & 2006 & & 1426 & 747 & $\$ 255$ & $\$ 174$ & 1115 & $\$ 206.08$ \\
\hline Aug & 2006 & & 1597 & 131 & $\$ 235$ & $\$ 150$ & 368 & $\$ 213.77$ \\
\hline July & 2006 & & 1226 & 237 & $\$ 240$ & $\$ 150$ & 237 & $\$ 218.60$ \\
\hline & Total & & 33,255 & 53,932 & & & & \\
\hline
\end{tabular}

Source: New Jersey Solar Renewable Energy Certificates (http://www.njcleanenergy.com/renewableenergy/programs/solar-renewable-energy-certificates-srec/public-reports/public-reports). 


\section{Political and Regulatory Consistency}

The success of any RPS policy depends not only on implementation specifics but also on the strength and consistency of the policy over time. Some RPS policies have had steady political support, including robust enforcement mechanisms, which instill confidence in the burgeoning renewables market for developers and investors alike. Other policies have suffered from vague regulations or definitions, frequent revisions, and lax enforcement.

\section{Strong RPS Policy Mechanisms}

The strongest RPS policies incorporate noncompliance penalties, either in the form of fines or an alternative compliance payment (ACP). An ACP requires suppliers to pay a predetermined amount (per kilowatt-hour) if they fall short in meeting the RPS. However, an ACP system allows load-serving entities to still claim that they are in compliance with the RPS rather than to be penalized for noncompliance. The ACP funds collected are normally used to support new renewable energy development. Table 5 lists noncompliance provisions for different RPS states.

Penalties and ACP systems become even stronger motivators if load-serving entities are prohibited from recovering these costs from ratepayers or customers. Montana and Pennsylvania are among the states that do not allow the recovery of noncompliance penalties in rates.

\section{Weak RPS Policy Mechanisms}

On the other end of the spectrum are states that enact ambiguous RPS regulations or definitions, allow frequent or major rule changes, or have weak enforcement mechanisms. For example, the RPS laws in Maine (prior to revision in 2007), Nevada, and Wisconsin allow state regulators to impose penalties for noncompliance, but the amount of the penalty and how or when it will be imposed is not clear.

Also, compliance waivers are available in many states. These provisions tend to be vague as to when and how a waiver is to be granted. For example, the Arizona statute allows a utility to request a waiver from any provision, "for good cause." 25 And in Hawaii, the Public Utilities Commission has, "the option to either grant a waiver from the renewable portfolio standard or an extension for meeting the prescribed standard." ${ }^{26}$ Some waivers are based on, "economic and competitive pressure" (Minnesota), ${ }^{27}$ or whether renewable resources are, "reasonably available" (Pennsylvania). ${ }^{28}$ In few cases, however, the laws provide guidance on when waivers can and should be granted, or on the length of time for which a waiver should be granted. 
Table 5. State RPS Policies and Noncompliance Penalties

\begin{tabular}{|c|c|}
\hline State & Noncompliance Penalty/Alternative Compliance Payment (ACP) \\
\hline Arizona & State regulators may impose but amount(s) not specified \\
\hline California & $5.0 \phi / \mathrm{kWh}$ noncompliance penalty \\
\hline Colorado & State regulators may impose but amount(s) not specified \\
\hline Connecticut & $5.5 \phi / \mathrm{kWh}$ noncompliance penalty \\
\hline Delaware & $\begin{array}{cc}\text { ACP system } \\
-2.5 \phi / \mathrm{kWh} \text { (first year of noncompliance) } \\
\text { - } \quad 5.0 \phi / \mathrm{kWh} \text { (second year of noncompliance) } \\
\text { - } \quad 8.0 \phi / \mathrm{kWh} \text { (third year of noncompliance and subsequent years) } \\
\text { ACP for solar: } \\
-\quad 25 \phi / \mathrm{kWh} \text { (first year of noncompliance) } \\
\text { - } \quad 30 \phi / \mathrm{kWh} \text { (second year of noncompliance) } \\
\text { - } \quad 35 \phi / \mathrm{kWh} \text { (third year of noncompliance and subsequent years) }\end{array}$ \\
\hline $\begin{array}{l}\text { District of } \\
\text { Columbia }\end{array}$ & $\begin{array}{cc}\text { ACP system } \\
& 2.5 \phi / \mathrm{kWh} \text { for Tier } 1 \text { resources } \\
\bullet \quad 1.0 \phi / \mathrm{kWh} \text { for Tier } 2 \text { resources } \\
\qquad \quad 30.0 \phi / \mathrm{kWh} \text { for solar } \\
\end{array}$ \\
\hline Hawaii & State regulators may impose but amount(s) not specified \\
\hline Illinois & State regulators may impose but amount(s) not specified \\
\hline lowa & None \\
\hline Maine & ACP for new capacity requirement start at $5.712 \phi / \mathrm{kWh}$, adjusted for inflation. \\
\hline Maryland & 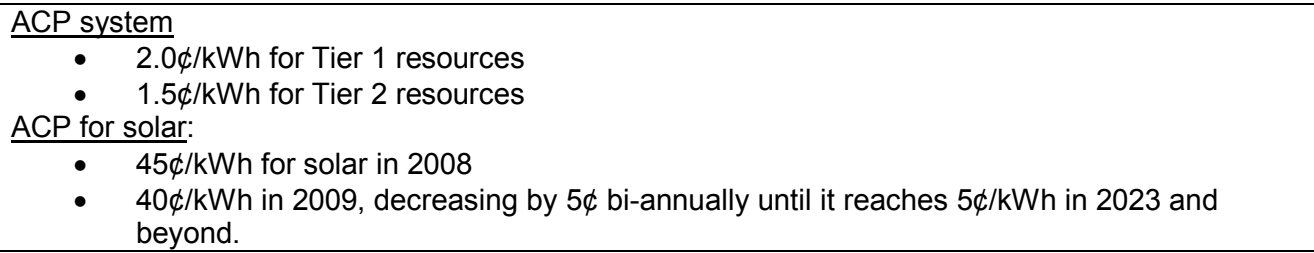 \\
\hline Massachusetts & $\begin{array}{ll}\text { ACP system: } \\
\\
& 5.0 \phi / \mathrm{kWh} \\
& \text { In } 2003, \text { adjusted annually for inflation, so was set at } \$ 57.12 \text { in } 2007\end{array}$ \\
\hline Minnesota & State regulators may impose but amount(s) not specified \\
\hline Montana & $1.0 \phi / \mathrm{kWh}$ noncompliance penalty \\
\hline Nevada & State regulators may impose but amount(s) not specified \\
\hline New Hampshire & $\begin{array}{ll}\text { ACP varies according to the four classes of eligible resources: } \\
\text { - } & 5.712 \phi / \mathrm{kWh} \text { for Class I (new renewables); } \\
\text { - } & 15 \phi / \mathrm{kWh} \text { for Class II (solar); and } \\
\text { - } & 2.8 \phi / \mathrm{kWh} \text { for Class III and IV (existing biomass, methane and hydroelectric). } \\
\end{array}$ \\
\hline New Jersey & $\begin{array}{ll}\text { ACP system } \\
\quad 5.0 \phi / \mathrm{kWh} \text { for Class I and II resources } \\
\quad 30.0 \phi / \mathrm{kWh} \text { for solar } \\
\end{array}$ \\
\hline New Mexico & State regulators may impose but amount(s) not specified \\
\hline New York & None (RPS is state-administered) \\
\hline North Carolina & State regulators may impose but amount(s) not specified \\
\hline Oregon & PUC establishes ACP for each compliance year for each electricity supplier \\
\hline Pennsylvania & $\begin{array}{ll}\text { ACP system (not recoverable in rates) } \\
& 4.5 \phi / \mathrm{kWh} \text { for Tier } 1 \text { and Tier } 2 \text { resources } \\
\bullet \quad & \text { For solar, } 200 \% \text { of average market value of solar credits } \\
\end{array}$ \\
\hline Rhode Island & ACP system: $5.0 \phi / k W h(2003 \$$, adjusted annually by the Consumer Price Index) \\
\hline Texas & $\begin{array}{l}\text { Noncompliance penalty is the lesser of } 5 \phi / \mathrm{kWh} \text { or } 200 \% \text { of the average cost of credits traded during } \\
\text { the year }\end{array}$ \\
\hline Washington & $5.5 \phi / \mathrm{kWh}$ noncompliance penalty \\
\hline Wisconsin & Noncompliance penalty of up to $\$ 500,000$ \\
\hline
\end{tabular}




\section{RPS Cost Caps}

Many states concerned about the potential rate impacts of an RPS have instituted cost caps which limit the exposure of ratepayers to higher costs associated with RPS implementation. In general, if a cost cap is reached, suppliers are exempted from further compliance requirements. A common methodology utilized for cost caps is a reasonable cost threshold. For example, the New Mexico RPS law contains a reasonable cost threshold beyond which utilities are no longer required to acquire renewable supply. And California has adopted a methodology for determining a preapproved reasonable cost beyond which the utility must apply for a supplemental energy payment (SEP); the compliance obligation could be limited to the amount that can be funded by available SEP funds.

Other states have capped their costs based on how much the state is willing to collect from ratepayers, regardless of whether the RPS requirement can be met. New York collects a set feebased on consumption per kilowatt-hour-from electricity ratepayers to cover the above-market costs of renewable purchases. The funds are managed by the New York State Energy and Research Development Authority (NYSERDA), the central RPS procurement agency for the state. To date, the funds collected appear to be inadequate to fully support the achievement of the RPS milestones. ${ }^{29}$

Colorado's RPS law limits the RPS charge to 1\% of a customer's bill; in New Mexico, the rate cap ranges from $1 \%$ to $2 \%$. In most cases, these cost caps are based on how much of a cost burden the state is willing to place on ratepayers and not on a calculation of the actual cost of meeting the RPS.

\section{Changing Eligibility Rules}

Suppliers and developers - and markets generally — value certainty. However, RPS policies that are subject to frequent changes introduce uncertainty into the market. In particular, some states have modified their renewable resource and technology eligibility definitions, or the manner in which renewable energy production, and thus compliance, is measured. This has resulted in large REC market price swings. For example, resource eligibility changes in Connecticut allowed a number of preexisting biomass plants to sell into the compliance market, causing REC market prices to fall sharply in 2005. And, in Texas, REC prices fell after a judge ordered the state Public Utility Commission to undo an ad hoc change it made to its RPS calculation procedure for 2005. Such uncertainty is a disincentive to investment in new renewable energy projects.

\section{Case Studies}

\section{Montana: Compliance Waiver Conditions}

The state of Montana's RPS compliance waiver is probably one of the most explicit; therefore, it provides a good example for other states to emulate. The law states that a "short-term waiver" may be granted if the utility can demonstrate it has, "undertaken all reasonable steps to procure renewable energy credits under long-term contract," or if the, "integration of additional" renewable energy technologies, "will clearly and demonstrably jeopardize the reliability of the electrical system." 


\section{Connecticut: Market Impact of Resource Eligibility Changes}

The Connecticut RPS has two tiers that target renewable technologies, Class I and Class II, with different eligibility criteria and supply requirements. The Class I supply requirement starts at $1 \%$ in 2004 and ramps up to 7\% in 2010. In addition, beginning in 2004, load-serving entities must provide 3\% of their supply from either Class I or Class II resources. The state's Class III requirement targets energy efficiency, load management and heat recovery.

In the original RPS legislation, Class I resources were defined to include wind, landfill methane, fuel cells, and solar photovoltaics, and REC prices ranged from $\$ 35-\$ 50$ per REC. However, in June 2003, the legislature amended the RPS to expand the definition of Class I resources to include a number of additional resources, including biomass plants that use "sustainable fuels" and meet standards for oxides of nitrogen $\left(\mathrm{NO}_{\mathrm{X}}\right)$ emissions. That opened the door for a number of existing biomass generation plants located in the New England region to become Class I eligible by installing additional $\mathrm{NO}_{\mathrm{X}}$ emission control equipment. As a result, the Connecticut RECs market became oversupplied in 2005, leading to a precipitous decline in REC prices from $\$ 35.50$ to $\$ 5.00$ within a few months. ${ }^{30}$ Two subsequent revisions in 2006 resulted in increased REC prices: 1) the legislature followed the lead of other New England states to only allow RECs from outside of the NEPOOL region if the REC imports match with physical energy imports on an hourly basis (presumably making it harder to import from outside of New England); ${ }^{31}$ and 2) the legislature passed an act that clarified that construction and demolition waste used to power a biomass electricity facility cannot be considered an eligible fuel for the Class I tier of their RPS. 32 As a result, REC prices jumped to $\$ 25-\$ 30$ and are now hovering just above $\$ 50$ per REC. Frequently updating the RPS can dramatically affect REC prices, as shown in Figure 4.

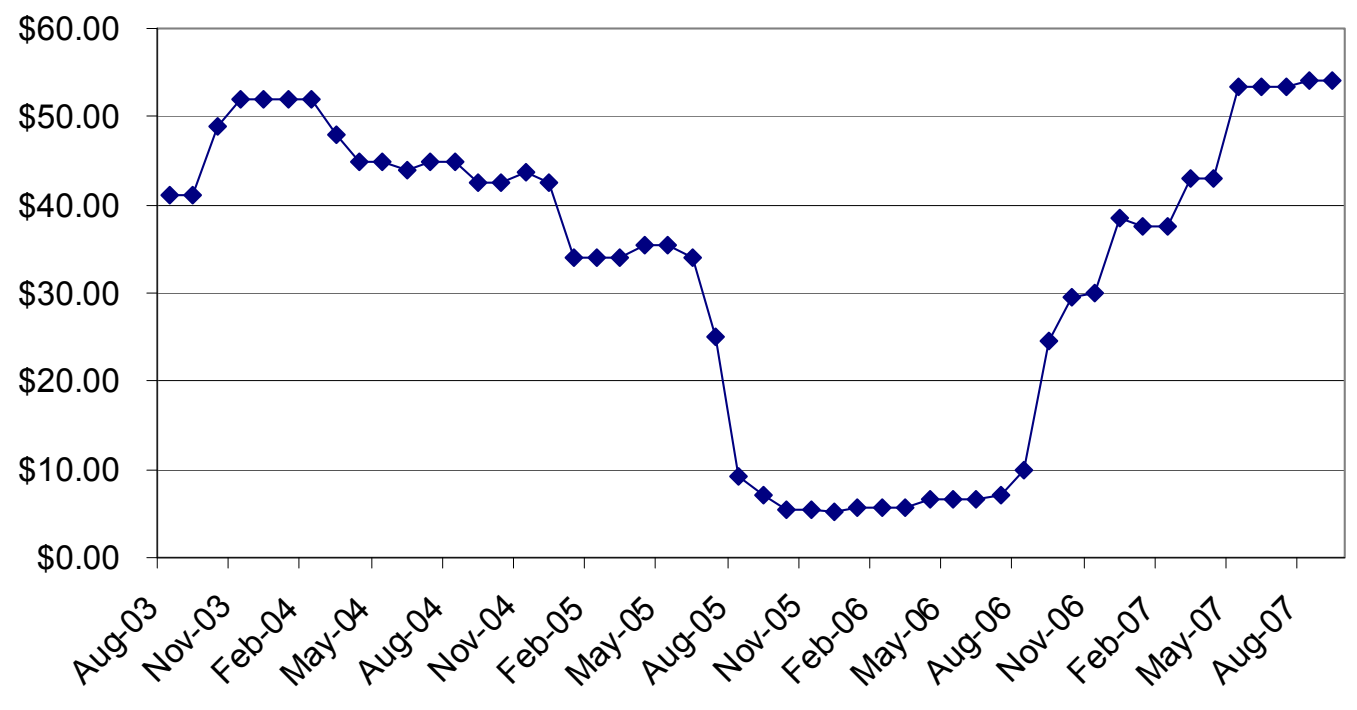

Figure 4. Connecticut Class I REC prices

Sources: Evolution Markets (www.evolutionmarkets.com) and Lawrence Berkeley National Laboratory.

\section{Massachusetts: Market Impact of Resource Eligibility Deliberations}

The Massachusetts RPS, enacted in 1997 as a component of the state's electricity restructuring law, requires that load serving entities provide at least $1 \%$ new (post-1997) renewable resources 
to their customers starting in 2003, increasing to $4 \%$ in 2009 , and adding $1 \%$ per year thereafter as determined by the Division of Energy Resources (DOER). Draft eligibility guidelines issued early in 2004 indicated that the DOER was leaning toward allowing the output from existing (pre-1997) biomass plants that retooled with, "low-emission, advanced" technology to qualify for RPS compliance. ${ }^{33}$

The result at that time was to halt the development of new facilities and instead encourage the retooling of $750 \mathrm{MW}$ of existing biomass plants. Ultimately, the new policy was not adopted, but the proposal created enough uncertainty that a number of potential new biomass projects were delayed, possibly extending the state's current RECs shortage. Upon further deliberation, the DOER issued a policy statement on October 27, 2005, that changed the earlier proposal to allow only the energy output in excess of a plant's historical generation rate to qualify for RPS compliance. ${ }^{34}$

\section{Texas: Price Impacts on RECs of Ad Hoc Adjustments to RPS Calculation}

The rule adopted by the Public Utility Commission of Texas (PUCT) implementing the Texas RPS sets forth the formula by which the statewide RPS requirement is calculated. One component of this formula is a capacity conversion factor (CCF), which converts the statutory renewable energy generation capacity requirement (in megawatts) into an equivalent quantity of energy (in megawatt-hours). For the first two years of the RPS - before any significant historical production data were available - the rule set the CCF at 35\%. From 2004 onward, however, the rule requires the $\mathrm{CCF}$ to be recalculated based on historical output from all renewable energy generation facilities in Texas that are eligible to earn RECs.

Nearly all the renewable capacity installed in 2001 and 2002 was wind power and was concentrated in one area in west Texas. The amount of wind power overloaded the existing transmission system, and curtailments in the area were frequent. Consequently, the CCF calculated from actual output during this time was $27 \%$ rather than the $35 \%$ to $40 \%$ it would have been, absent the transmission bottlenecks. Because this would have reduced the statewide RPS requirement, a coalition of wind power developers petitioned the PUCT to set the CCF at a higher number for 2004. The commission agreed and ordered the CCF to be maintained at 35\% for 2004 and 2005.

Retail electric providers (REPs) have the burden of compliance under the RPS, and one appealed the PUCT's decision. The court found that the commission could not act contrary to its own rules without going through the proper procedures for amending a rule, and ordered the PUCT to reset the CCF to $27 \%$. Not only was the 2005 RPS requirement reduced, the excess requirement that had been assigned for 2004 based on the 35\% CCF was credited to all REPs' 2005 requirement. All told, the RPS for 2005 was about half the 2004 RPS. Along with a surge of new wind power construction that increased the supply of RECs, the CCF case temporarily contributed to a sharp decline in the spot price of Texas RECs from more than $\$ 12$ in 2005 to less than $\$ 5$ in 2006. 


\section{Ability to Finance Projects}

In the end, all the rules and conditions established for an RPS policy must allow new projects to be built, meaning entities must be willing to risk the capital investment required for project development. RPS requirements by themselves are not adequate to ensure that new renewable energy supply will come on line. Each separate element of an RPS policy must be addressed in turn, and the final hurdle is to secure project financing.

\section{Market Structure}

Market structure can play a role in implementing an RPS and in the ability to finance projects, particularly whether the market is regulated with a single electricity provider or restructured for market competition. Regulated utilities with a captive customer base and cost recovery guarantees are better positioned to make investments in new generation or to execute long-term power purchase contracts with renewable energy project developers. In restructured markets, electricity generation and distribution responsibilities are often separated - in some cases, distribution utilities are precluded from making generation investments - and retail customers can switch from one provider to another, making long-term investment planning difficult and risky for suppliers.

However, market structure alone does not predetermine the outcome of an RPS policy. For example, Texas, a restructured market, has already met its initial RPS target, while Nevada, a regulated market, has consistently missed its targets. And Colorado, a regulated market, will reach its RPS target early, while Massachusetts, a restructured market, has struggled to meet its targets. While market structure is an important influence, other RPS implementation factors may be equally as important.

\section{Financial Community Expectations}

The financial community controls access to the debt and equity funding needed for most new renewable energy generation projects. Financiers are experts in identifying risks and minimizing uncertainties associated with their potential investments, and they require that very stringent standards be met before they will invest in a project.

Revenue risk and investment risk are two of the first considerations. Reducing revenue risk often requires that a project have a power purchase agreement (PPA) long enough to assure revenues during the debt repayment period, generally eight to 15 years. While some wind projects are able to depend on other revenue support mechanisms, ${ }^{35}$ most renewables and many wind projects still depend on PPAs. It is also critical to have a creditworthy purchaser, which helps assure investors that the purchaser will remain solvent and thus be able to honor the purchase agreement. Investment risks include such factors as resource adequacy, technology and equipment performance, and securing siting and permitting approvals. Tax incentives reduce overall project costs and also lower the investment risk.

Investment risks, perceived or actual, are often greater for renewable energy projects than for conventional energy projects. Despite having lower operational costs, renewable projects tend to be capital intensive and therefore require more up-front debt and equity investment before becoming operational. Conventional projects require a smaller up-front investment (per unit of energy), but are subject to fuel-cost uncertainty, the risk of which is usually passed through to 
ratepayers in the form of higher fuel prices. However, fossil fuel projects in the United States might increasingly be subject to the regulatory risk of carbon emission regulations, which are already occurring in California and the northeastern U.S. ${ }^{36}$ Many investors perceive renewable technologies as "emerging" and thus a greater investment risk, since they are relatively new in comparison to well-established conventional generation. Moreover, some renewable technologies are dependent on favorable weather conditions, and output varies over a day, season, and year. Because annual production swings could be as much as $\pm 20 \%$, there are concerns over whether production, and thus revenues, will be sufficient to recover investments.

RPS policies support demand rather than supply. They require that a certain amount of load be met with specified renewable resources, but they do not automatically include provisions to ensure that financing can be secured for new projects. Because RPS policies are usually the creation of a state legislature or regulatory authority, they are subject to legislative and regulatory changes. Therefore, these market drivers may be subject to significant regulatory uncertainty, which the financial community tries to avoid. The risk is alleviated somewhat if projects can tap multiple markets; for example, by being eligible to meet any of several state RPS requirements or by providing generation for voluntary renewable energy purchase markets.

RPS implementation experience to date shows that development has been most successful where developers have been able to secure long-term contracts with creditworthy counterparties. In fact, several states require utilities to sign long-term power purchase contracts with eligible renewable energy developers. States with such contracting requirements include: California (10+ years), Colorado (20+ years), Connecticut (100 MW for 10+ years), Iowa (own project or "sign long-term contract"), Maryland (15+ years for solar only), Montana (10+ years), Nevada (10+ years), North Carolina ("sufficient length" for solar), and Pennsylvania ("good faith effort," including "seeking...long-term contracts."). In states and regions where short-term trade in RECs dominates over long-term contracting, RPS policies appear to be a costly and unstable way of achieving renewable energy objectives. Where long-term contracts are available or required, RPS policies have largely been successful. ${ }^{37}$

Where these financial conditions cannot be met, states have attempted to remedy the situation. For example, the Massachusetts system benefit charge fund offers long-term REC contracts to developers of fairly mature projects, which are offered as either a direct REC purchase or as a purchase option. New York employs a state-operated procurement program into which project developers bid to receive production incentives. And Nevada has established a temporary fund to guarantee utility power purchase contracts until utility credit ratings improve.

\section{Changing Financial Landscape}

There are other policy options that could influence whether projects are financed. The most notable one is a feed-in tariff which places a legal obligation on utilities to purchase electricity from renewable energy generators at a guaranteed rate for a determined length of time. Widely used in Europe, feed-in tariffs have been credited for advancing renewable energy development, particularly in Germany.

Feed-in tariffs patterned after those in Europe have been implemented or are under consideration in a number of states in the U.S. For example, Minnesota that has a "Community Based Energy Development (C-BED)" program to provide 20-year contracts to small renewable projects. The program was expanded in 2007 to include all renewable technologies (initially only wind was included) in order to insure utility rate recovery (tariffs proposed by the utility, based on 20-year 
net present value of projects), to allow utility participation, and to eliminate the $2.7 \notin$ per $\mathrm{kWh}$ rate cap. ${ }^{38}$ Another example is the legislation passed in the state of Washington in 2005 that established a technology-specific feed-in tariff for solar PV, small wind, and biogas projects. Residences, businesses, or local governments can participate and are able to secure a credit of at least $15 \not$ per $\mathrm{kWh}$, which can increase to as high as $54 \phi$ per $\mathrm{kWh}$, if the generator or its components were manufactured in Washington State. However, there is an annual limit of \$2000 which is expected to support the typical output of a $3.5 \mathrm{~kW}$ PV system. ${ }^{39}$ There are some challenges with this tariff in addition to the annual limit, including that payment is guaranteed for only 10 years, and no payments will be made after June 30, 2014. ${ }^{40}$ There are several proposals for feed-in tariffs as well. On December 5, 2007, the California Energy Commission recommended that the state adopt feed-in tariffs to spur lagging renewable energy development in order to meet the state's RPS target of $33 \%$ by $2020 .{ }^{41}$ Similar feed-in tariffs are being proposed and considered in Hawaii, Michigan, Oregon, and Wisconsin. ${ }^{42}$

\section{Case Studies}

\section{State Contract Guarantees: Two Approaches}

In both Massachusetts and New York, renewable energy project developers have faced financing challenges. Utilities in both states are no longer in the generation business, and retail electricity providers are unable or unwilling to enter into long-term power purchase contracts. There is also concern about changing RPS rules. While both states face similar situations, each designed a different approach to addressing these concerns.

The Massachusetts Technology Collaborative (MTC), administrator of the state's renewable system benefit charge fund, offers long-term REC contracts to developers of fairly mature projects. These contracts are offered as either a direct REC purchase or as a purchase option, in which developers can decide each year whether to sell their RECs to the MTC at a fixed price, or sell them in the market if they would bring a better price. The contracts are backed with funds already accumulated from ratepayers.

To assure lenders of adequate cash flow for REC purchases, the MTC escrows the money with a third-party in the name of the particular project. The arrangement is much like a revolving loan program. If the project is not built for any reason, the escrowed funds are returned to the MTC. If the project is built and the MTC ends up with the RECs, it will sell them in the REC market to recover some portion of the funds. In signing these contracts, the MTC helps minimize REC price uncertainties for project developers and takes on the market risks associated with future REC demand and value.

The MTC contracts address only the value of RECs and not energy output. Developers still need sufficient energy revenues to satisfy lenders' requirements. Also, the MTC funding is not sufficient to fulfill the entire Massachusetts RPS.

New York took a different approach to this issue, deciding to employ a state-operated procurement program to meet its RPS. Under the program, which is operated by NYSERDA, 
new renewable energy project developers can bid for production incentives from the state, as long as they sell their power to New York and do not sell the attributes elsewhere or retire them.

The incentives are funded through an RPS-specific charge on customers' bills. However, like the situation in Massachusetts, the current level of funds being collected appears inadequate to fully meet the state's RPS requirements.

\section{Nevada Addresses Utility Creditworthiness}

Project financing under utility regulation is normally straightforward: utilities either invest in their own projects or sign long-term power purchase contracts with project developers. But in Nevada, the western United States' energy crisis of 2000-2001 left the state's two investorowned utilities in a weakened financial condition. No longer viewed as creditworthy by the investment community, renewable energy project developers were unable to obtain financing for new projects that would be built to meet the state RPS. Investors were not convinced that the utilities were solvent enough to supply a dependable revenue stream to the projects.

Nevada's solution was to establish a Temporary Renewable Energy Development Fund (TRED), which guarantees utility contracts on a temporary basis until the utilities' credit ratings improve. The TRED is financed through a renewable energy charge on customers' bills, and the funds are transferred to the independent TRED Trust, which makes payments to renewable developers. By instituting a ratepayer-backed payment mechanism that bypasses the utility, the TRED has alleviated the financial community's concern about revenue risk. However, questions remain for Nevada regarding how long the TRED mechanism will be needed and whether the creditworthiness of the utilities will improve enough to satisfy investors. 


\section{Summary and Conclusions}

In the end, a successful RPS policy is one that meets a particular state's policy goals. States may enact an RPS with any number of policy goals in mind, such as fuel diversity, economic development, electricity price stability, environmental benefits, and others. However, policy makers should keep in mind that the pursuit of some goals, such as maximizing in-state development, could come at the expense of the achievement of other goals, such as minimizing the cost impacts of an RPS. Here, we summarize some of the insights gained from this review.

Renewable resource availability and quality varies widely across the regional climates and geographies of the United States, and some states are better endowed with certain resources than others. Accordingly, most state rules permit the use of renewable energy certificates, or RECs, to meet RPS requirements. Generally, the use of RECs helps suppliers minimize their compliance costs by tapping the most economic resources, although many states place limits on their ultimate reach. REC tracking systems help verify RECs ownership and protect against double counting.

However, RECs eligibility criteria are not uniform across all states, which has implications for many facets of RPS implementation. Most state RPS laws and regulations agree on the inclusion of wind and solar energy resources as well as methane sources derived from landfill gas and anaerobic digestion of some biomaterials. Eligibility is less uniform for hydropower, geothermal, municipal solid waste, biomass, and fuel cells. States have also adopted different rules around the eligible life of a REC and REC banking. Ultimately, different state REC definitions will need to be harmonized to allow for broader trade between states and REC tracking systems.

Pressure remains for states to realize the economic development benefits of their RPS policies. Rather than unduly restricting access to potentially less costly out-of-state resources, which in some cases may run afoul of federal interstate commerce laws, states can provide incentives to encourage in-state generation projects and renewable energy industries.

Solar technologies have been the primary beneficiaries of resource set-asides in RPS policies. However, states face some unique challenges with system output verification because of the potentially large number of small systems and because most systems are located "behind the meter" at customers' sites. It is still too early to judge the effectiveness of solar set-asides, as these provisions are just starting to operate; therefore, little actual experience has been documented. However, solar set-asides are likely to be most successful where they are combined with significant incentives and strong enforcement mechanisms, including noncompliance penalties.

Ultimately, to be successful, RPS policies must have consistent and enforceable rules. Factors that increase market uncertainty include compliance waivers, low cost thresholds, vague resource and technology eligibility definitions, and weak (or no) enforcement penalties. All of these factors can make the RPS policy less predictable and compromise success. Encouraging market certainty and ensuring clarity in RPS regulations are critical to policy success. While mid-course policy corrections may be warranted, any changes should take full account of the potential impacts on market prices and investor confidence. 
Finally, market structure can play an important role in RPS implementation, particularly if the market is regulated or restructured. States need to consider the entities responsible for RPS compliance, and understand their respective abilities and willingness to invest in, or otherwise support, new renewable projects, particularly within restructured electricity markets. Where generation responsibilities are unclear or where corporate creditworthiness is an issue, states should be prepared to step in with innovative financing strategies. 


\section{Notes and References}

${ }^{1}$ U.S. Environmental Protection Agency. "Clean Energy-Environment Guide to Action, 2006." www.epa.gov/cleanrgy/stateandlocal/guidetoaction.htm.

${ }^{2}$ Much of the information on individual state requirements comes from the Union of Concerned Scientists, Table C-1, State Minimum Renewable Electricity Requirements (as of January 2007), 2007 , at

http://www.ucsusa.org/assets/documents/clean_energy/State_Renewable_Energy_Standards.pdf and the Database of State Incentives for Renewables \& Efficiency, at http://www.dsireusa.org/.

${ }^{3}$ Schwartz, A. "Renewable Energy Certificates and the California Renewables Portfolio Standard Program." Staff White Paper, California Public Utilities Commission, Division of Strategic Planning, April 20, 2006. http://www.cpuc.ca.gov/published/Report/55606.htm.

${ }^{4}$ Holt, E.; Bird, L. "Emerging Markets for Renewable Energy Certificates: Opportunities and Challenges." NREL/TP-620-37388. Golden, CO: National Renewable Energy Laboratory, January 2005. http://www.eere.energy.gov/greenpower/resources/pdfs/37388.pdf.

${ }^{5}$ Bird, L.; Swezey, B. "Green Power Marketing in the United States: A Status Report (Ninth Edition)." NREL/TP-640-40904. Golden, CO: National Renewable Energy Laboratory, November 2006. http://www.eere.energy.gov/greenpower/resources/pdfs/40904.pdf. ${ }^{6}$ Holt, E. A.; Wiser, R. H. "The Treatment of Renewable Energy Attributes and Green Power Programs in State Renewables Portfolio Standards.” LBNL-62574. Berkeley, CA: Lawrence Berkeley National Laboratory, April 2007. . . http://eetd.lbl.gov/ea/EMS/reports/62574.pdf

${ }^{7}$ Minnesota Public Utilities Commission. Order after Reconsideration, In the Matter of Detailing Criteria and Standards for Measuring an Electric Utility's Good Faith Efforts in Meeting the Renewable Energy Objectives; Under Minn. Stat. § 216B.1691, Docket No. E-999/CI-03-869; August 13, 2004.

${ }^{8}$ Texas Legislature, S.B. No. 20 (2005), Section 3(m), at www.capitol.state.tx.us/tlodocs/791/billtext/doc/SB00020F.doc.

${ }^{9}$ Texas Legislature, S.B. No. 1090 (2007), Section 2 (m-3), at http://www.capitol.state.tx.us/tlodocs/80R/billtext/htm1/HB01090F.HTM

${ }^{10}$ Administered by the San Francisco-based Center for Resource Solutions, the Green-e program (at www.green-e.org) certifies retail and wholesale green power products that meet its environmental and product content standards. In 2005, the Green-e program certified about half of the renewable energy sold in the U.S. voluntary green power market. The EPA Green Power Partnership (at www.epa.gov/greenpower) encourages U.S. organizations to voluntarily purchase green power as a way to reduce the risk of climate change and the environmental impacts associated with conventional electricity use.

${ }^{11}$ Bird, L.; Lokey, E. "Interaction of Compliance and Voluntary Renewable Energy Markets" NREL/TP-670-42096. Golden, CO: National Renewable Energy Laboratory, October 2007. http://www.nrel.gov/docs/fy08osti/42096.pdf

${ }^{12}$ Stambler, B. PPM Energy, "Supplying Green Power in Compliance and Voluntary Markets" presentation. Austin, Texas: Tenth National Green Power Marketing Conference; October 26, 2005. www.eere.energy.gov/greenpower/conference/10gpmc05/stambler.pdf.

${ }^{13}$ Holt, E. A.; Wiser, R;. Bolinger, M. "Who Owns Renewable Energy Certificates? An Exploration of Policy Options and Practices." LBNL-59965. Berkeley, CA: Lawrence Berkeley National Laboratory; April 2006. http://eetd.lbl.gov/ea/emp/reports/59965.pdf.

${ }^{14}$ In an October 1, 2003, decision, the Federal Energy Regulatory Commission (FERC) declared that, under PURPA, QF power purchase contracts do not automatically convey RECs to the 
purchasing utility (absent an express provision in a contract to the contrary), but left the issue for states to decide based on state law. See 105 FERC 9 61,004, United States of America Federal Energy Regulatory Commission. Docket No. EL03-133-000, Order Granting Petition for Declaratory Order. www.ferc.gov/whats-new/comm-meet/100103/E-1.pdf.

${ }^{15}$ Cory, K.; Bolgen, N.; Sheingold, B. "Long-Term Revenue Support to Help Developers Secure Project Financing." Conference Proceedings of Global Windpower 2004. Chicago, IL; March 2004. www.masstech.org/renewableenergy/green power/MGPPpaperAWEA.pdf

${ }^{16} \mathrm{http}: / /$ epa.gov/greenpower/gpmarket/tracking.htm.

17 See www.resource-solutions.org/policy/naaib/.

${ }^{18}$ New York State Public Service Commission. "Proceeding on Motion of the Commission Regarding a Retail Renewable Portfolio Standard: Order on Delivery Requirements for Imports from Intermittent Generators.” Case 03-E-0188; June 28, 2006.

www3.dps.state.ny.us/pscweb/WebFileRoom.nsf/Web/5518DB5DC89F609C85257199005416B F/\$File/381 03e0188 0628 06.pdf.

${ }^{19}$ For a comprehensive list of state renewable energy incentives, see the Database of State Incentives for Renewables and Efficiency. http://www.dsireusa.org/.

${ }^{20}$ Ferry, S. "Renewable Orphans: Adopting Legal Renewable Standards at the State Level." The Electricity Journal, Vol. 129, Issue 2, 2006; pp. 52-61.

${ }^{21}$ Programs that directly encourage solar or distributed generation include Arizona, Colorado, Delaware, Maryland, Nevada, New Hampshire, New Jersey, New Mexico, New York, North Carolina, Pennsylvania, Washington and Washington DC. Some of the programs use more than one mechanism described to promote solar.

${ }^{22}$ Parker, S. "Maryland Expands RPS: 1,500 MW Solar by 2022" Renewable Energy Access, April 12, 2007, at http://www.renewableenergyaccess.com/rea/news/story?id=48102

${ }^{23}$ New Jersey Clean Energy Program, "Solar Installation Projects: (2001 - Aug 31, 2007)," New Jersey Board of Public Utilities, http://www.njcleanenergy.com/renewable-energy/programupdates/core-activity/solar-installation-projects/solar-installation-projec

${ }^{24}$ New Jersey Clean Energy Program website "New Jersey Solar Renewable Energy Certificate Program," http://www.njcleanenergy.com/renewable-energy/programs/solar-renewable-energycertificates-srec/new-jersey-solar-renewable-energy

${ }^{25}$ Arizona Corporation Commission, "In the Matter of the Proposed Rulemaking for the Renewable Energy Standard and Tariff Rules," Docket No RE-00000C-05-0030, Decision No. 68566, March 14, 2006, at http://www.cc.state.az.us/utility/electric/RES-03-14-06.pdf.

${ }^{26}$ Hawaii State Legislature, SB173 CD1, 2001. http://www.capitol.hawaii.gov/session2001/bills/HB173 cd1_htm.

${ }^{27}$ Minnesota State Senate, S.F. No. 4, 2007. http://www.revisor.leg.state.mn.us/bin/bldbill.php?bill=S0004.1.html\&session=1s85.

${ }^{28}$ Pennsylvania General Assembly, SB 1030, November 17, 2004, at http://www2.legis.state.pa.us/WU01/LI/BI/BT/2003/0/SB1030P1973.pdf.

${ }^{29}$ New York State Energy Research and Development Agency, New York State Renewable Portfolio Standard Program Performance Report (Program Period Ending December 2005), 2006, at www.dps.state.ny.us/2005 RPS Status Report Final.pdf.

${ }^{30}$ Zajak, J. "Is the Connecticut REC market wrecked?" SNL Energy Renewable Energy Week; Vol. 1, Issue 15, September 23, 2005. http://www.snl.com/InteractiveX/article.aspx?CDID=A2149787-11102

${ }^{31}$ U.S. Department of Energy's New England Wind Forum - Connecticut Wind Activities. http://www.eere.energy.gov/windandhydro/windpoweringamerica/ne astate template.asp?statea $\underline{b=c t}$ 
${ }^{32}$ Connecticut Substitute Senate Bill No. 212 and Public Act No. 06-74. "An Act Concerning Biomass.” http://www.cga.ct.gov/2006/ACT/Pa/pdf/2006PA-00074-R00SB-00212-PA.pdf.

${ }^{33}$ Massachusetts Division of Energy Resources, "Draft Guideline on the Regulations with Regard to the MA RPS Eligibility of Generation Units That Re-Tool with Low Emission, Advanced Biomass Technologies.” April 16, 2004.

http://www.mass.gov/doer/rps/r-comm.pdf.

${ }^{34}$ Massachusetts Division of Energy Resources. "Policy Statement on the RPS Eligibility of Retooled Biomass Plants.” October 27, 2005.http://www.mass.gov/doer/rps/rps-pol-stat-eligbiomass.pdf.

${ }^{35}$ In regions where the electricity market is restructured and where natural gas plants are the marginal units (that set the market clearing price), wind farm owners are starting to use electric and natural gas derivatives to provide long-term revenue certainty for their projects. . . In addition, some recent wind projects are moving forward without having their full energy and/or REC output under contract, and are therefore called quasi-merchant facilities. . While these mechanisms are currently only being used for wind, they might be used for other renewables in the future.

${ }^{36}$ Bird, L.; Holt, E.; Carroll, G. "Implications of Carbon Regulation for Green Power Markets." NREL/TP-640-41076. . . Golden, CO: National Renewable Energy Laboratory, April 2007. http://www.nrel.gov/docs/fy07osti/41076.pdf

${ }^{37}$ Wiser, R.; Porter, K.; Grace, R. "Evaluating Experience with Renewable Portfolio Standards in the United States," Conference Proceedings of Global Windpower 2004. Chicago, IL; March 2004. http://eetd.lbl.gov/ea/ems/reports/54439.pdf.

${ }^{38}$ Nelson, C. "Summary of 2007 Minnesota Legislation Relating to Community Wind," June 2007. . http://www.c-bed.org/pdf/MN Project Summary_2007_Legislation.pdf

${ }^{39}$ Broehl, J. "Washington State Passes Progressive Renewable Energy Legislation," Renewable Energy Access, May 10, 2005.

http://www.renewableenergyaccess.com/rea/news/story;jsessionid=a9o2iOpVdxue?id=28478

${ }^{40}$ Washington State Senate, Senate Bill 5101 from the $59^{\text {th }}$ legislature (2005 regular session). . . http://www.leg.wa.gov/pub/billinfo/2005-06/Pdf/Bills/Senate\%20Passed\%20Legislature/5101S.PL.pdf

${ }^{41}$ Gipe, P. "California Energy Commission To Recommend Renewable Energy Feed-in Tarriffs; First Formal Endorsement of the Policy in the USA." Wind-Works website, December 4, 2007. . http://www.wind-works.org/FeedLaws/USA/CECConsidersFeed-inTariffs.html

${ }^{42}$ Gipe, P. "Renewable Tariffs and Standard Offer Contracts in the USA," Wind-Works website, December 4, 2007 (accessed December 20, 2007). http://www.windworks.org/FeedLaws/USA/USAList.html 


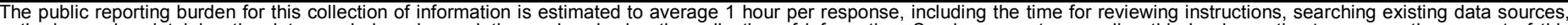

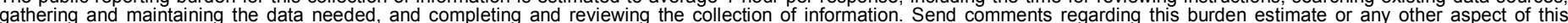

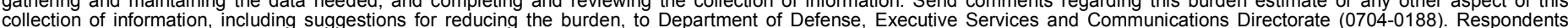

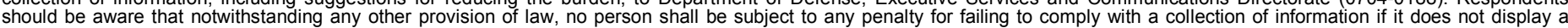

should be aware that notwithstanding

PLEASE DO NOT RETURN YOUR FORM TO THE ABOVE ORGANIZATION.

\begin{tabular}{l|l|l|l} 
1. REPORT DATE $(D D-M M-Y Y Y Y)$ & 2. & REPORT TYPE & 3. DATES COVERED (FrOm - TO)
\end{tabular}

December 2007

Technical Report

4. TITLE AND SUBTITLE

Renewable Portfolio Standards in the States: Balancing Goals and Implementation Strategies. 5a. CONTRACT NUMBER

DE-AC36-99-G010337

5b. GRANT NUMBER

5c. PROGRAM ELEMENT NUMBER

5d. PROJECT NUMBER

NREL/TP-670-41409

5e. TASK NUMBER

WF6N.1015

5f. WORK UNIT NUMBER
7. PERFORMING ORGANIZATION NAME(S) AND ADDRESS(ES)

National Renewable Energy Laboratory

1617 Cole Blvd.

Golden, CO 80401-3393

9. SPONSORING/MONITORING AGENCY NAME(S) AND ADDRESS(ES)
8. PERFORMING ORGANIZATION REPORT NUMBER

NREL/TP-670-42266
10. SPONSOR/MONITOR'S ACRONYM(S) NREL

11. SPONSORING/MONITORING AGENCY REPORT NUMBER

12. DISTRIBUTION AVAILABILITY STATEMENT

National Technical Information Service

U.S. Department of Commerce

5285 Port Royal Road

Springfield, VA 22161

\section{SUPPLEMENTARY NOTES}

\section{ABSTRACT (Maximum 200 Words)}

This paper reports on renewable portfolio standards (RPS) and how the RPS rules vary from state to state. This variation presents important challenges to successful implementation. Key issues are discussed in terms of resource availability, solar-specific provisions, and political and regulatory consistency, and their impacts on the ability to finance new renewable energy projects. This report emphasizes the fact that a successful RPS policy must balance a state's goals for fuel diversity, economic development, price effects, and environmental benefits.

\section{SUBJECT TERMS}

NREL; renewable portfolio standards; RPS policies; political consistency; regulatory consistency; RPS policy mechanisms; RPS eligibility rules; resource availability; RECs; Karlynn Cory; Blair Swezey

\begin{tabular}{l} 
16. SECURITY CLASSIFICATION OF: \\
\begin{tabular}{|l|l|l|}
\hline a. REPORT & b. ABSTRACT & c. THIS PAGE \\
Unclassified & Unclassified & Unclassified \\
& & \\
\hline
\end{tabular} \\
\hline
\end{tabular}

\begin{tabular}{|c|c|}
\hline $\begin{array}{l}\text { 17. LIMITATION } \\
\text { OF ABSTRACT }\end{array}$ & $\begin{array}{l}\text { 18. NUMBER } \\
\text { OF PAGES }\end{array}$ \\
\hline UL & \\
\hline
\end{tabular}

\section{9a. NAME OF RESPONSIBLE PERSON}

19b. TELEPHONE NUMBER (Include area code) 